\title{
The treatment of metastatic prostate carcinoma with BNCT in the ITU TRIGA MARKII reactor on rat model
}

\author{
Zafer Akan ${ }^{1}$, Hulya Ozdemir ${ }^{2}$, Gokhan Oto ${ }^{2}$, Hatice Uslu ${ }^{3}$, Mehmet Turkmen ${ }^{4}$, Mehmet \\ Bilgehan Yuksel ${ }^{5}$
}

\begin{abstract}
Objective: The delivery of curative radiotherapy is commonly has the potential of serious side effects. These side effects still remain dose-limiting factor for external beam radiotherapy and as also curative treatment of prostate cancer (PCa). New treatment alternatives, such as BNCT, are investigated to eliminate these limitations and to improve the therapeutic efficiency of radiation on tumour cells including prostate cancer. In this study, we investigated the efficiency of BNCT application by using our novel $10 \mathrm{~B}$ carrier that was called as 10B-DG on PCa using an in vivo mouse xenograft model.
\end{abstract}

Material and Methods: PCa bearing Copenhagen rats (CRs) were used in this experimental animal study. A total of $12 \mathrm{CRs}$ at the age of 2 months were used in this experimental animal study. MAT-LyLu PCa cells were injected subcutaneously into the peritoneal cavity of rats to create PCa model. The samples were divided into 4 groups: As, control, neutron irradiated, 10B-DG and 10B-DG + neutron irradiated group. 10BDG was administrated to tumour bearing rats and rats were exposed to $8.074 \mathrm{gy} / \mathrm{hr}$ thermal and epithermal. Tumour sizes were regularly measured by microtome and PET scan along 20 days.

Results: The results have shown that the tumor growth were regressed just in 10B-DG + neutron irradiated group. In addition that, PET-CT scan results revealed that 18 FDG uptake was stopped in the BNCT treated group due to metabolic inactivation of ablated tumor tisue.

Conclusion: This study revealed that BNCT treatment can be successfully performed by using our novel 10B carrier 10BDG in the management of PCa. We suppose that this novel 10B carrier can take place as a safe and effective agent in routine clinical practice of BNCT.

Keywords: BNCT, Prostate cancer, Rat model, BDG, FDG, Positron emittion tomography, Turkey

\section{Introduction}

Boron neutron capture therapy (BNCT) is a two-stage treatment modality, which stays on the basis of selective accumulation of non-radioactive boron-10 (10B) into the tumor cells via boron carriers and then irradiation of 10B loaded tumor cells with low-energy, thermal and epithermal neutrons $(\leqslant 10 \mathrm{keV})(\approx 109 \mathrm{n}$ $\mathrm{sec} / \mathrm{cm} 2)$. The capturing of these neutrons by $10 \mathrm{~B}$ causes the nuclear fission reactions, which result in the release of high toxic alpha particles $(4 \mathrm{He})$ and $7 \mathrm{Li}$ nuclei (1-4). The destroying cytotoxic effects of the irradiation are limited to the $10 \mathrm{~B}$ carrying tumor cells and normal surrounding tissue is protected related to the short path lenghts of these particles $(5-10 \mu \mathrm{m})$, which have lethal effect for approximately one cell diameter. As a result, tumor tissue can be selectively destroyed by BNCT application. But, the success and selectivity to the tumor cells of BNCT is due to the sufficiently accumulation large amounts of $10 \mathrm{~B}$ in the tumor cells (15-30 ppm) (5-9). Thus, the major principle of this application is sufficiently transport and accumulation of $10 \mathrm{~B}$ just into the tumor cells by $10 \mathrm{~B}$ carriers. Despite considerable drug development efforts, the commonly used and approved 10B delivery compounds are sodium borocaptate (BSH), boranophenylalanine (BPA), and polyhedral borane dianion (GB-10) with limited tumor cell specificity $(10,11)$. Therefore, the developement of new delivery agents with more effectivity and tumor cell sensitivity is required to improve the deficiencies of current agents.

Received 06-12-2016 Accepted 22-12-2016 Available Online 30-12-2016

1 Celal Bayar University School of Medicine, Department of Biophysics, Manisa, TR

2 Yüzüncü Y1l University School of Medicine, Department of Pharmacology, Van, TR

3 Istanbul Medeniyet University, School of Medicine, Department of Nuclear Medicine, Istanbul, TR

4 Hacettepe University, Faculty of Engineering, Dept. of Nuclear Engineering, Ankara, TR

5 Celal Bayar University School of Medicine, Department of Urology, Manisa, TR

* Corresponding Author: Zafer Akan E-mail: zaferakan@marmara.edu.tr Phone: +44 02032899294 
Our study group have newly developed a novel $10 \mathrm{~B}$ carrier (2R)-4,5,6-trihydroxy-2(hydroxymethyl)tetrahydro-2H-pyran-3-yl)boronic acid (BDG). Biodistrubiton analyse result has shown that that 10B succesfully and specifically accumulated in the tumor tissue by the 10BDG and had also antiproliferative and antiapoptotic effects against tumor cells $(12,13)$. In the present in vivo study, we assessed the efficacy of BDG as a novel 10B carrier and the success of BNCT application by using BDG in prostate cancer $(\mathrm{PCa})$ model in rats. In addition, the direct antiproliferative and cytotoxic effects of BDG on PCa cells was also investigated in this experimental study.

\section{Materials and Methods}

\section{Synthesis of BDG}

10B-DG was synthesezed according to previous literature and results (14). $0.1 \mathrm{M}$ boric acid $(\mathrm{B}(\mathrm{OH}) 3$; Sigma-Aldrich, B6768) and 0.5 M deoxy-D-glucose (DG: Sigma-Aldrich, D8375) solutions were prepared with the same volumes of deionised water and incubated for $20 \mathrm{~min}$. at $\mathrm{pH}: 3$ and $37^{\circ} \mathrm{C}$. Both solutions were then mixed in the same tube and incubated for one hour at $\mathrm{pH}: 3$. The $\mathrm{pH}$ was gradually increased from $\mathrm{pH}: 3$ to $\mathrm{pH}: 7$ and stabilised at a physiologic $\mathrm{pH}$ (pH:7.4). The 10BDG complexation reaction was tested using a Fourier Transform Infrared Attentuated Total Reflectance spectroscopy (FTIR/ATR), as previously described (12). An aqueous solution of the BDG complex was prepared at a concentration of $250 \mathrm{mg} / \mathrm{ml}(21.28 \mathrm{mg} 10 \mathrm{~B} / \mathrm{ml})$. In previous studies, the calculated non-toxic dose was about $30 \mathrm{mg}$ BDG $/ \mathrm{kg}$ and this dose was used for BNCT applications in Copenhagen Rats $(12,15)$.

Neutron Irradiation Time and Dose Calculations For 10B nuclear decay efficiency calculation, the 2.5 ppm 10B-DG in the $5 \mathrm{ml}$ distilled water were irradiated with $8.074 \mathrm{gy} / \mathrm{hr}$ neutron flux in a duration of $80 \mathrm{~min}$ in the previously modified radial port of Istanbul Technical University TRIGA MARK II nuclear reactor (13). Nuclear decay time and efficiency of $10 \mathrm{~B}$ were calculated due to ICP-OES $10 \mathrm{~B}$ analysis in the samples (Figure 1). $10 \mathrm{~B}+1 \mathrm{n} \rightarrow$ $4 \mathrm{He}+7 \mathrm{Li}$ nuclear disintegration reaction was stabilized at $60 \mathrm{~min}$ due to diminish of $10 \mathrm{~B}$ in the solution (Figure 1), and exposure time selected as $60 \mathrm{~min}$. for tumour bearing Copenhagen Rats and total exposure dose measured and calculated as 8.074 Gy/hours.

\section{Neutron Energy Spectrum}

Spectrum of the neutrons in a neutron beam is important from the viewpoint of total dose to be accumulated inside the tumor cells. Due to huge neutron cross-section of $10 \mathrm{~B}$ isotope in thermal energy, epithermal neutrons are more suitable for the tumor cells located deeper than $8 \mathrm{~cm}$ as such as brain cancers whereas thermal neutrons are for superficial tumors. Epithermal neutrons slow down due to high hydrogen content of cells as they pass through the tissue and they become thermal neutrons at the tumor site. In this study, the neutron beam of radial beam port of Istanbul Technical University TRIGA MARK II research reactor is utilized to irradiate the CRs. This port supplies thermal and fast neutrons, and photons besides epithermal neutrons. For dose calculations, neutron energy groups are divided as thermal $(\mathrm{E}<$ $0.414 \mathrm{eV})$, epithermal $(10 \mathrm{keV}>\mathrm{E}>0.414 \mathrm{eV})$ and fast $(\mathrm{E}>10 \mathrm{keV})$

\section{MAT-LyLu Cell Culture}

Prostate cancer MAT-LyLu cell line (ATCC JHU-92) was purchased from the American Type Culture Collection (ATCC, Rockville, MD, USA). The cells were maintained in RPMI1640 supplemented with $10 \%$ fetal bovine serum (FBS) and $1 \%$ penicillin/streptomycin (Life Technologies Inc.) at $37^{\circ} \mathrm{C}$ in a $5 \% \mathrm{CO} 2$ atmosphere.

\section{Experimental Animal PCa model}

MAT-LyLu cells were collected from cell culture and washed with phospate buffer saline (PBS, SigmaAldrich, P4417). $10 \mu \mathrm{l}$ PBS including $1 \times 106$ cells were subcutaneously injected by an insuline needle into the peritoneum of $6 \sim 8$ weeks old Copenhagen Rats under anesthesia, which was provided by Ketamine hydrocloride (50 mg/kg, Phizer). The day of injection was taken as the initiation point and defined as day 0 . At 4 th day of MAT-LyLu cell injection, the MAT-LyLu xenografts were observed in a palpable size. A total of 12 tumor bearing Copenhagen rats (6 8 weeks old) were divided into four groups (Group 1: untreated Control, Group 2: 10B-DG administrated, Group 3: Neutron irradiated, Group 4: 10B-DG administrated and Neutron irradiated groups). At seventh day subsequent to intraperitoneal tumor implantation, the peritoneum of rats were detected by Ultrasonography (USG) and Positron Emition Tomography (PET) imaging, and average tumour size was measured $12 \mathrm{~mm}$ in diameter in all rats. In Groups 3 and 4, the tumors in the peritoneum were exposed to thermal neutron beam irradiation at Istanbul Technical University TRIGA MARK II Nuclear Reactor for $60 \mathrm{~min}$ at a power of $250 \mathrm{KW}$.

Each rat was kept in a particularly produced PolyEthylene cage during exposure. $\mathrm{Pb}$ layer blocks were used to shield the body from scattered neutron and Gama rays while the tumor-bearing peritoneum was exposed to neutron irradiation. Experimental animal ethic application and study permissions were supplied by the Yuzuncu Yil University, Experimental animal study ethic commission.

\section{BNCT experimental procedure}

After 4 hours fasting, $30 \mathrm{mg} / \mathrm{kg}$ 10B-DG $(5 \mathrm{mg} / \mathrm{kg}$ 10B) was administrated to rats via tail vein. Fourty minutes after the injection, the rats were exposed to a total $8.074 \mathrm{~Gy} / \mathrm{hr}$ thermalized and epi-thermalized neutron radiation in a duration of 1 hour at 8 th and 
19th days of cancer cell implantation. A detailed demonstration of the experimental flow chart was clearly described in Table 1.

Tumour sizes were measured with microtome and PET regularly for 25 days. Tumor volume measurements were performed once a week and calculated using the formula: length $\mathrm{x}$ width $\mathrm{x}$ depth $\mathrm{x}$ 0.5236

Table 1: BNCT Study flow chart.

\begin{tabular}{|c|c|c|c|c|}
\hline & Group $1(n=3)$ & Group $2(n=3)$ & Group $3(n=3)$ & Group $4(n=3)$ \\
\hline First day & $\begin{array}{l}\text { 1x10 } 0^{6} \text { MAT-LyLu } \\
\text { cell implantation }\end{array}$ & $\begin{array}{l}1 \times 10^{6} \text { MAT-LyLu } \\
\text { cell implantation }\end{array}$ & $\begin{array}{l}1 \times 10^{6} \text { MAT-LyLu } \\
\text { cell implantation }\end{array}$ & $\begin{array}{l}1 \times 10^{6} \text { MAT-LyLu cell } \\
\text { implantation }\end{array}$ \\
\hline $4^{\text {th }}$ day & $\begin{array}{l}\text { Tumour size } \\
\text { measurement }\end{array}$ & $\begin{array}{l}\text { Tumour size } \\
\text { measurement }\end{array}$ & $\begin{array}{l}\text { Tumour size } \\
\text { measurement }\end{array}$ & Tumour size measurement \\
\hline $7^{\text {th }}$ day & $\begin{array}{c}\text { Tumour size } \\
\text { measurement and } \\
\text { PET analysis }\end{array}$ & $\begin{array}{l}\text { Tumour size } \\
\text { measurement and } \\
\text { PET analysis }\end{array}$ & $\begin{array}{l}\text { Tumour size } \\
\text { measurement and } \\
\text { PET analysis }\end{array}$ & $\begin{array}{c}\text { Tumour size measurement } \\
\text { and PET analysis }\end{array}$ \\
\hline $8^{\text {th }}$ day & Control Group & ${ }^{10} \mathrm{~B}-\mathrm{DG}$ & Neutron & ${ }^{10} \mathrm{~B}-\mathrm{DG}+$ Neutron \\
\hline $11^{\text {th }}$ & $\begin{array}{l}\text { Tumour size } \\
\text { measurement }\end{array}$ & $\begin{array}{l}\text { Tumour size } \\
\text { measurement }\end{array}$ & $\begin{array}{l}\text { Tumour size } \\
\text { measurement }\end{array}$ & Tumour size measurement \\
\hline $15^{\text {th }}$ & $\begin{array}{l}\text { Tumour size } \\
\text { measurement }\end{array}$ & $\begin{array}{l}\text { Tumour size } \\
\text { measurement }\end{array}$ & $\begin{array}{l}\text { Tumour size } \\
\text { measurement }\end{array}$ & Tumour size measurement \\
\hline $19^{\text {th }}$ & $\begin{array}{c}\text { Tumour size } \\
\text { measurements and } \\
\text { PET analysi }\end{array}$ & $\begin{array}{l}\text { Tumour size } \\
\text { measurement and } \\
\text { PET analysis }\end{array}$ & $\begin{array}{l}\text { Tumour size } \\
\text { measurement and } \\
\text { PET analysis }\end{array}$ & $\begin{array}{c}\text { Tumour size measurement } \\
\text { and PET analysis }\end{array}$ \\
\hline $19^{\text {th }}$ day & Ex. & Ex. & Ex. & ${ }^{10} \mathrm{~B}-\mathrm{DG}+$ Neutron irradiated \\
\hline $20-25^{\text {th }}$ days & & & & Tumour size measurements \\
\hline
\end{tabular}

Table 2. Dose Equivalent (Gy/hr) of Neutron Flux/Photon Fluence at the Collimator Exit of Radial Beam Port

\begin{tabular}{llcc}
\hline \multirow{2}{*}{ Particle } & Energy group & ICRP & Polyethylene Colimator \\
Neutron & Thermal & 2.844 & NCRP \\
& Epithermal & 4.378 & 1.976 \\
Photon & Subtotal & 7.222 & 3.629 \\
& Fast & 0.852 & 5.605 \\
& Overall & 8.074 & 1.415 \\
\end{tabular}

Thermal $(\mathrm{E}<0.414 \mathrm{eV})$, Epithermal $(10 \mathrm{keV}>\mathrm{E}>0.414 \mathrm{eV})$, Fast $(\mathrm{E}>10 \mathrm{keV})$

Table 3: Mean values of Quality factors based on NCRP and ICRP

\begin{tabular}{lcc}
\hline $\begin{array}{l}\text { Radiation type } \\
\text { and energy }\end{array}$ & $\begin{array}{c}\text { Quality factor } \\
\text { (ICRP Pub. 103 } \\
\text { 2007 Reccom.) }\end{array}$ & $\begin{array}{c}\text { Quality factor } \\
\text { NCRP-38 }\end{array}$ \\
\hline Photons, all energies & 1 & 1 \\
Thermal Neutrons: $\mathrm{E}<0.414 \mathrm{eV}$ & 2.5 & 2 \\
Epithermal Neutrons: $0.414 \mathrm{eV}<\mathrm{E}<10 \mathrm{keV}$ & 2.5 & 2 \\
\hline
\end{tabular}


Table 4: Mean values of Conversion factors based on NCRP and ICRP

\section{Radiation type and energy}

\section{Flux-to-Dose Rate Conversion Factor \\ (ICRP-21)}

(rem/hr per n/cm2.s)
Photons, all energies

Thermal Neutrons: $\mathrm{E}<0.414 \mathrm{eV}$

Epithermal Neutrons: $0.414 \mathrm{eV}<\mathrm{E}<10 \mathrm{keV}$

\subsection{E-6}

4.41E-6

4.13E-6

\section{Flux-to-Dose Rate \\ Conversion Factor \\ NCRP-38}

(rem/hr per n/cm2.s)

$3.83 \mathrm{E}-6$

$4.28 \mathrm{E}-6$

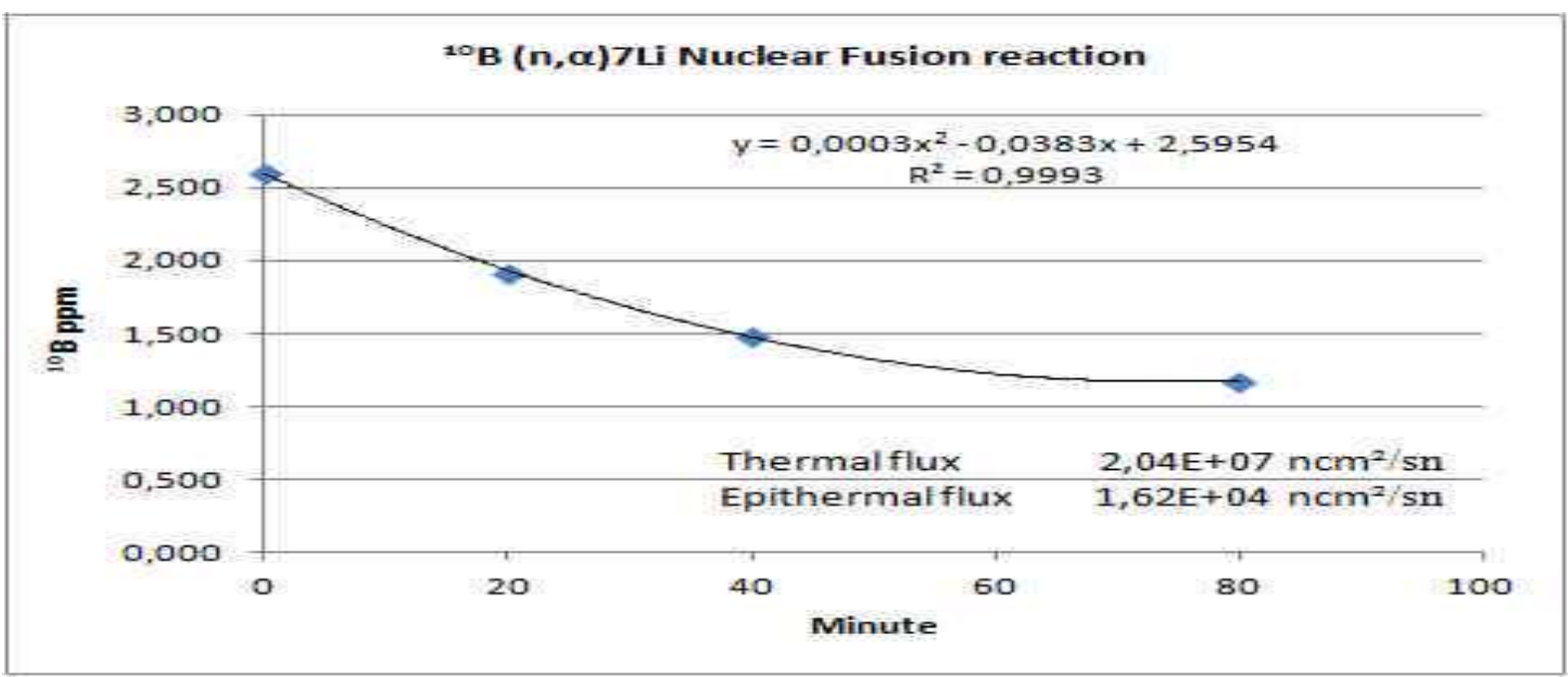

Figure 1. Boron decay; The $3 \mathrm{ppm}{ }^{10} \mathrm{~B}$ including ${ }^{10} \mathrm{~B}(\mathrm{OH}) 3$ were irradiated in collimated radial port of TRIGA MARK II Nucleer Reactor with thermal and epithermal neutrons. Nuclear fussion reaction of 10B in modified radial beam port was clearly detected by ICP-OES measurements.

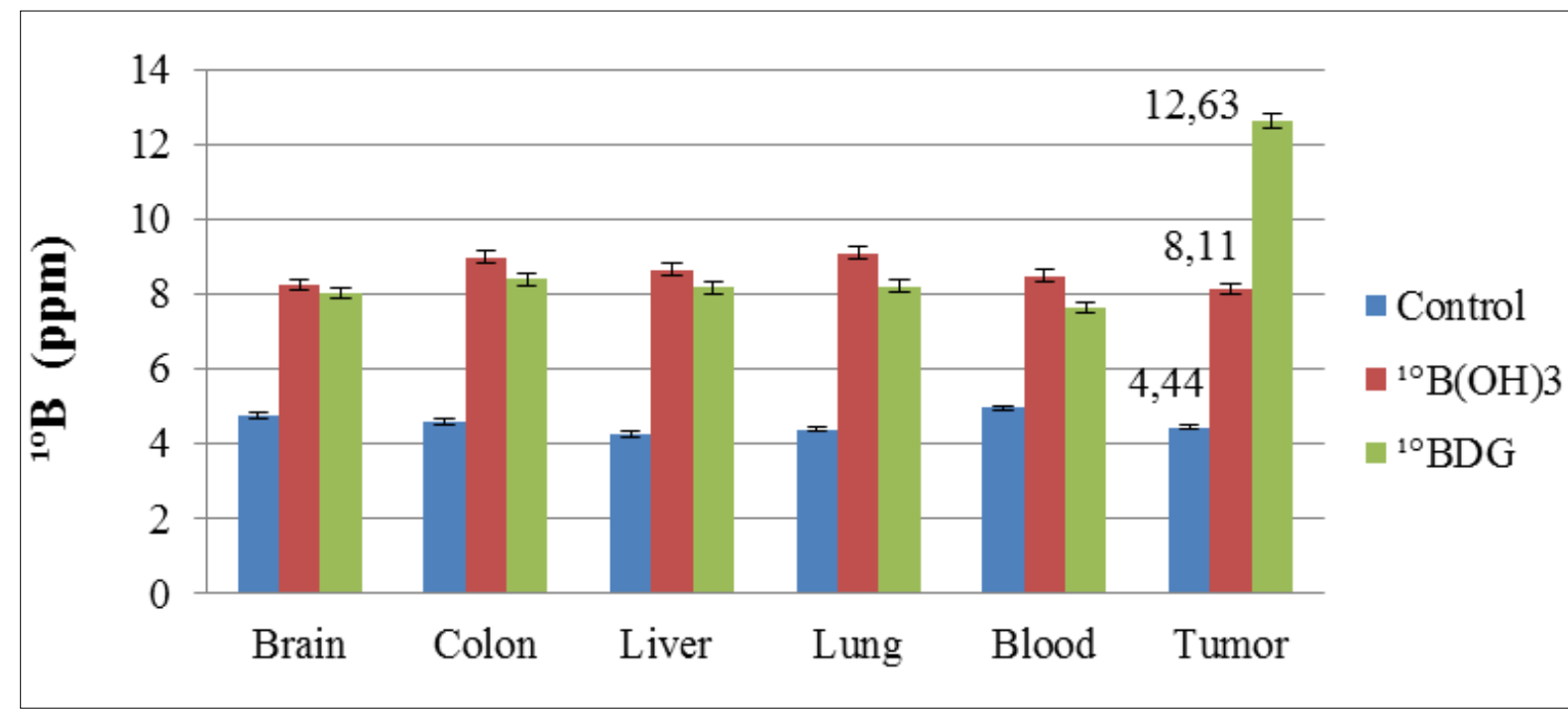

Figure 2: Bio-distribution analyse result of $10 \mathrm{~B}$ in tumor bearing rats. $6 \mathrm{mg} / \mathrm{kg} 10 \mathrm{~B}$ containing $30 \mathrm{mg} / \mathrm{kg}$ 10B-DG were administrated to the tumor bearing Copenhagen Rats via tail vein and 40 minutes later, all rats were executed; Brain, Colon, Liver, Lung, Blood, and Tumor tissues were removed and Boron contents were analaysed with ICP-OES. ( $n=3$, Bars represents, Mean \pm SD) (12). 
Bio-distribution analysis result of $10 \mathrm{~B}$ in tumor bearing rats.

The $30 \mathrm{mg} / \mathrm{kg} \quad 10 \mathrm{~B}$ containing 10B-DG were administrated to the tumor bearing Copenhagen Rats via tail vein and 40 minutes later, all rats were executed; Brain, Colon, Liver, Lung, Blood, and Tumor tissues were removed and Boron contents were analaysed with ICP-OES. $(n=3$, Bars represents, Mean \pm SD)

\section{PET-CT analysis of BNCT applied Tumour bearing Copenhagen Rats.}

As known, metabolization of FDG indicates to tumour tissue survival. Examination of peritoneum by Ultrasonography (USG) and Positron Emition Tomography (PET-CT) imaging has revealed a significant tumor growth and 18-FDG uptake, which was a sign of an active tumour tissue (Figure $3 a, 3 b$ ).
At the following 18th day, the PET-CT imaging has shown a significant regression of 18-FDG uptake in xnegraft in BNCT treated group (Figure $4 \mathrm{~b}$ ). There was no significant difference due 18 -FDG uptakes at 7 th and 18th days in control group (Figure 3a, b). Especiall in figure $4 \mathrm{~b}, \mathrm{FDG}$ signal was clearly detected in bladder but not detected in tumour tissue of BNCT applied group which indicates to cancer cells have lost their vitality in neutron radiated area (Figure 4b).

The measurement of tumor size has revealed that the average tumour size was determined $12 \mathrm{~mm}$ in diameter at seventh day of the tumor implantation. While tumor size progressively increased in group 1,2, and 3; tumor growth slowly decelerated and remained stable in group 4 after 18th day of the implantation due to BNCT treatment. The growing curves of CRs tumours were clearly demonstrated in Figure 5.
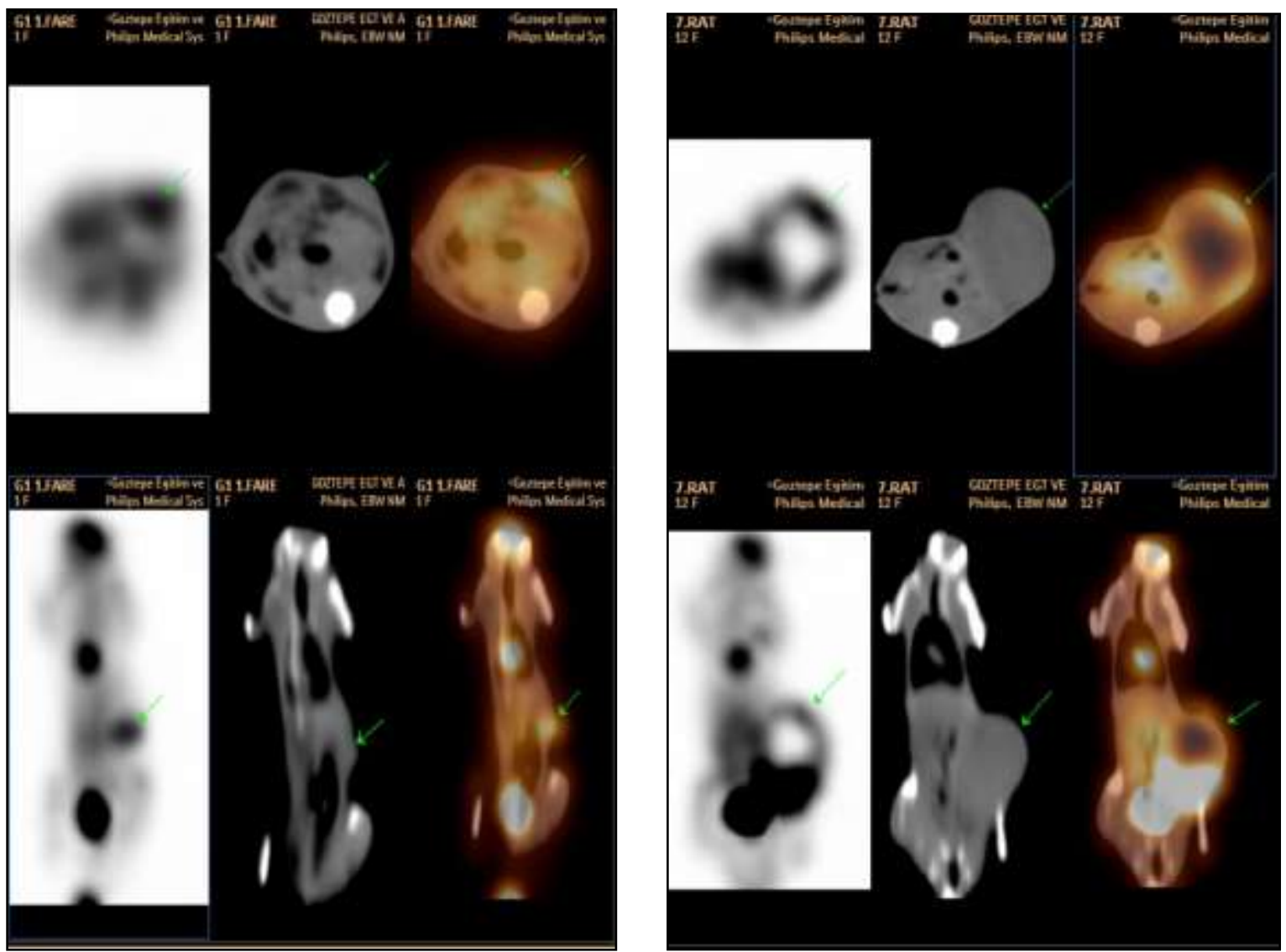

Figure 3: Control Group. PET image of Mat LyLu PCa cell implanted Copenhagen Rats (CRs). 3a: PET image of Control group CRs at 7th day of Mat LyLu PCa cell implantation. 18-FDG uptake is active as expected 3b: PET image of Control group CRs at 18th day of Mat LyLu PCa cell implantation. 18-FDG uptake is active as expected and Tumour growth aggressive. 

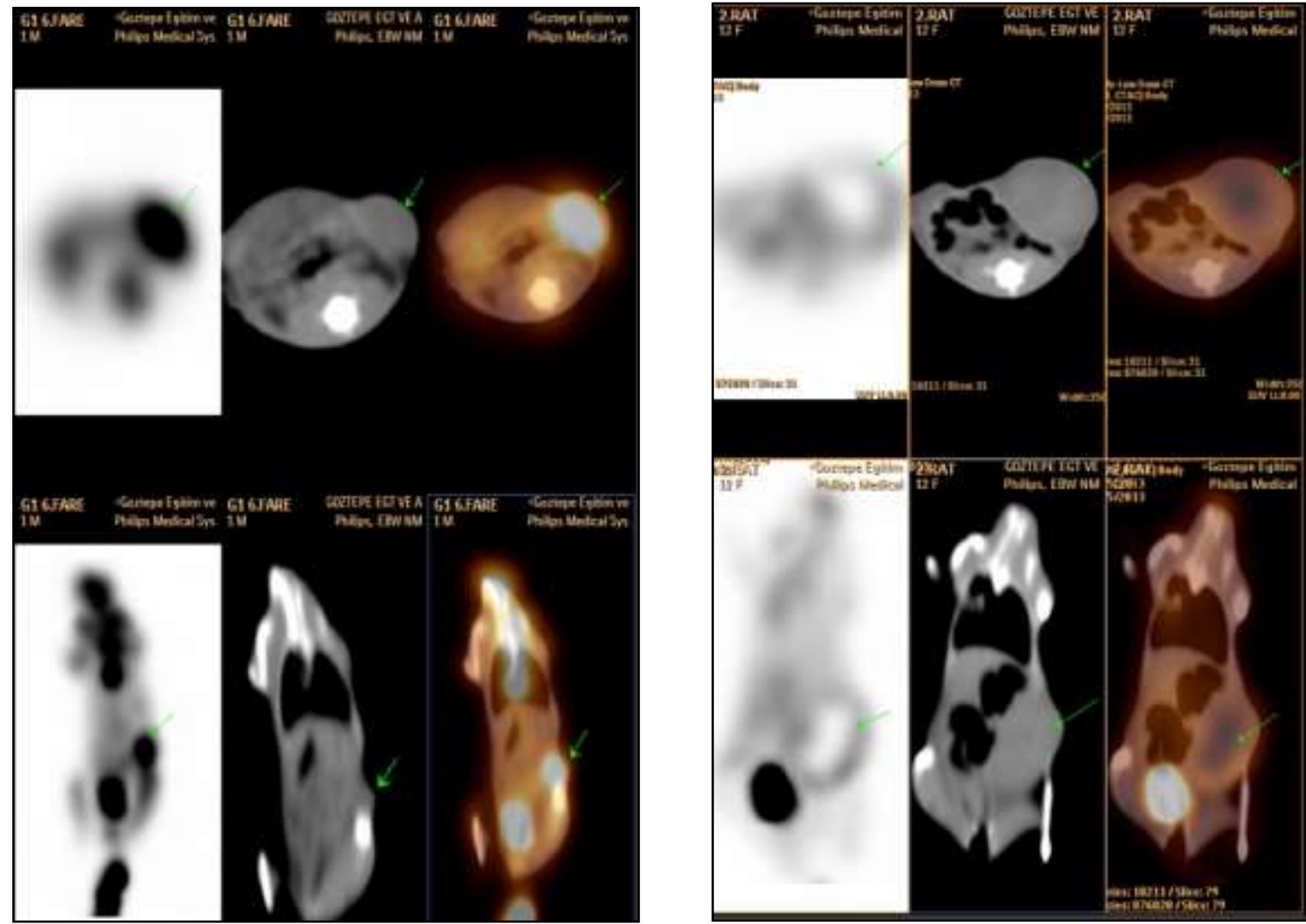

Figure 4: BNCT applied group: PET image of Mat LyLu PCa cell implanted Copenhagen Rats (CRs). 4a: PET image of BNCT applied group CRs at 7th day of Mat LyLu PCa cell implantation. 18-FDG uptake is active as expected 4b: PET image of BNCT applied group CRs at 18th day of Mat LyLu PCa cell implantation (After BNCT application with 10BDG boron carrier). 18-FDG uptake is not active due to success of BNCT application.

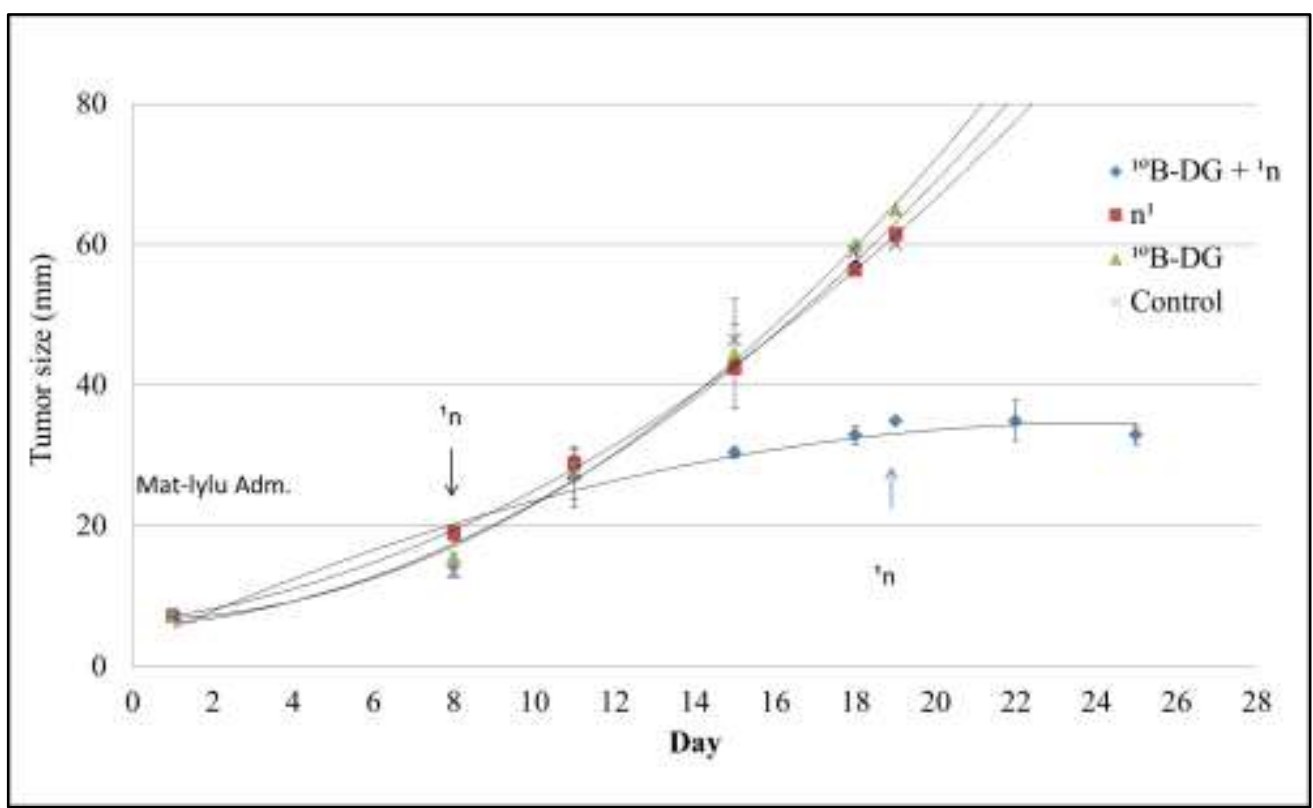

Figure 5: The demonstration of tumor growth among the four groups. Tumor growth slowly decelerated and remained stabile just in group 4 (BNCT applied group) after 18th day of the implantation. 


\section{Discussion}

Prostate cancer (PCa) is known to be the most common cause of noncutaneous cancer and the sixth leading cause of cancer death among elderly males worldwide. More than 700,000 new cases develop in each year, and the worldwide PCa burden is expected to grow up related to aging $(16,17)$. At the end of the 20 th century, PCa has become a more common health problem especially in developed countries (18). In the worldwide, the incidence of PCa increases, likely related to an increased awareness of the population regarding $\mathrm{PCa}$, widespreadly use of $\mathrm{PCa}$ screening and expended information about the nature and survey of the illness $(19,20)$. As a result of these developements, the amount of incidental and localized $\mathrm{PCa}$ cases have been increased, cancer specific mortality has been decreased, and the overall life expectancy increased in many parts of the world. However, increasingly use of prostate specific antigen (PSA) as a marker of the disease resulted in early diagnosis of $\mathrm{PCa}$ at early stage and increased requirement of curative and minimal invasive treatment alternatives $(20,21)$.

Although surgery and radiotherapy are commonly used curative treatment alternatives, surveillance can be the treatment of choice particularly in some older men with low volume cancers and severe comorbidities (22). Radiotherapy can be performed by two different ways including external beam radiotherapy with advanced imaging technologies and brachytherapy. It has been known that higher radiation doses are required for optimal cancer control and can provide better cancer-free survival, and there is a significant relation between cytotoxic effects for tumour cells and normal tissue complications of external beam radiotherapy. The delivery of curative radiotherapy is commonly has the potential of occurrence of serious side effects. These side effects still remains dose-limiting factor for external beam radiotherapy. Nevertheless, higher doses of radiation can be achieved by brachytherapy inside prostatic tissue without damaging of adjacent structures, but it has also some limitations. (23-25). New treatment alternatives, such as BNCT, are investigated to eliminate these limitations and to improve the therapeutic efficiency of radiation on tumour cells. The principal of these researches is based on the differences of biological mechanisms between the cancerous and normal tissues, thus the maximal radiation dose can be achived by particularly targeting the damaged biological mechanisms in the neoplastic cells, increased the therapeutic effect of radiation in neoplastic tissue and decreased undesired adverse effects by not to effect the molecular mechanisms in normal tissues.

BNCT is a tumour selective treatment method for all tumour tissues and based on intracellular accumulation and destruction of the stable boron isotope, $10 \mathrm{~B}$ with neutron radiation to 7litium and 4helium. The success of BNCT is depending on to two factors: Appropriate neutron dose and accumulation of sufficient $10 \mathrm{~B}$ in the tumor cells $(15-30 \mathrm{ppm})(26)$. A wide spectrum of boron carrying agents have been developed, but only two drugs are commonly using (sodium borocaptate $=\mathrm{BSH}$ and borono phenylalanine BPA) in clinical trials.

Dose calculations and combine usage of tumor selective boron carrier borono phenylalanine (BPA) and non specific boron carrier sodium borocaptate (BSH) depends on kind and site of tumour. Due to dose dependent side effects and non specific boron acumulations restricts the usage of BNCT for different cancer treatment for this reason synthesis of new boron carriers have great interest between the BNCT researchers.

There have very few basic or clinical studies of BNCT in the field of PCa. For example, increased tumor cell damage in BNCT application by using BPA in PCa cell line- DU145 has been shown (27). Recently, Gifford et al. reported that liposome-based delivery of a boron-containing cholesteryl ester compound $(\mathrm{BCH})$ was capable of carrying sufficient boron into PC3 cells for BNCT, and that $10 \mathrm{~B}$ thermal neutron capture significantly increased the killing of targeted PC3 cells in vitro (28). Takahara et al. performed invivo experimental studies regarding the effectiveness of BPA-mediated BNCT in mice, in which androgenindependent $\mathrm{PCa}$ cell line-PC3 has been implanted. This study demonstrated that BPA mediated BNCT significantly delayed PCa growth, and BPA-mediated BNCT decreased PCa progression without affecting apoptosis.

\section{Conclusion}

In this study, usage of new boron carrier, glucose complexed 10B (10B-DG) has been investigated on prostate cancer $(\mathrm{PCa})$ treatment. As to our results, $\mathrm{PCa}$ may successfully was treated with BNCT. Expecially BNCT treatment with new boron carriers BDG may give advantages for life quality of $\mathrm{PCa}$ patients. Moreover, new 10B carrier 10BDG may give new advantages to cancer patients such as all body irradiation therapy modalities for metastatic cancer patients. Low cost, easy synthesis procedure and carrier properties of $10 \mathrm{BDG}$ may give a new perspective to researchers for BNCT usage.

Neutron source problem for BNCT had been solved by the Sumitomo BNCT group with new proton accelerator (29). In near future routine usage of BNCT may be possible with new Boron carrier and neutron source technologies. 
Conflict of Interest: The authors declare no potential conflicts of interest with respect to the research, authorship, and/or publication of this article.

Acknowledgement: Author Contributions: ZA: Concept,Design, Invivo and Invitro studies, writing of article, HO, GO.: Synthesis of 10BDG, Invivo studies, HU: PET-CT imaging, and evaluation, MT: Neutron source planning and coordination, MBY: PCa modelling, and analysis, Article Writing, Editing.

This project was supported by National Boron Research Institute Turkey (BOREN). We are grateful to the ITU TRIGA MARKII Nuclear reactor Operators, and Istanbul Medeniyet University Nuclear Medicine Department workers.

Ethical issues: All Authors declare that Originality of research/article etc... and ethical approval of research, and responsibilities of research against local ethics commission are under the Authors responsibilities. The study was conducted due to defined rules by the Local Ethics Commission guidelines and audits.

\section{References}

1. Barth RF, Coderre JA, Vicente MG, Blue TE. Boron neutron capture therapy of cancer: current status and future prospects. Clinical Cancer Research. 2005 Jun 1;11(11):3987-4002.

2. Coderre JA, Chanana AD, Joel DD, Elowitz EH, Micca PL, Nawrocky MM, Chadha M, Gebbers JO, Shady M, Peress NS, Slatkin DN. Biodistribution of boronophenylalanine in patients with glioblastoma multiforme: boron concentration correlates with tumor cellularity. Radiation research. 1998 Feb 1;149(2):163-70.

3. Coderre JA, Morris GM. The radiation biology of boron neutron capture therapy. Radiation research. 1999; 151(1):1-18

4. Uusi-Simola J, Savolainen S, Kangasmaki A, Heikkinen S, Perkio J, Ramadan UA, et al. Study of the relative doseresponse of BANG-3((R)) polymer gel dosimeters in epithermal neutron irradiation. Physics in Medicine and Biology. 2003;48(17):2895-906.

5. van Rij CM, Wilhelm AJ, Sauerwein WAG, van Loenen AC. Boron neutron capture therapy for glioblastoma multiforme. Pharmacy World \& Science. 2005;27(2):92-5.

6. Hopewell JW, Gorlia T, Pellettieri L, Giusti V, H-Stenstam B, Skold K. Boron neutron capture therapy for newly diagnosed glioblastoma multiforme: An assessment of clinical potential. Applied Radiation and Isotopes. 2011;69(12):1737-40

7. Barth RF, Soloway AH, Brugger RM. Boron neutron capture therapy of brain tumors: past history, current status, and future potential. Cancer investigation. 1996 Jan $1 ; 14(6): 534-50$

8. Chen W, Mehta SC, Lu DR. Selective boron drug delivery to brain tumors for boron neutron capture therapy. Advanced drug delivery reviews. 1997 Jul 7;26(2):231-47.
9.

Soloway, A.H.; Tjarks, W.; Barnum, B.A.; Rong, F.; Barth, R.F.; Codognic, I.M.; Wilson, J.G. The chemistry of neutron capture therapy. Chem. Rev. 1998, 98, 1515-1562.

10. Barth, R.E. A critical assessment of neutron capture therapy; an overview. J. Neuroncol. 2003, 62, 1-5.

11. Gupta, N.; Gahbauer, R.A.; Blue, T.E.; Albetson, B. Common challenges and problems in clinical trials of boron neutron capture therapy. J. Neuroncol. 2003, 62, $197-210$.

12. Akan Z., Ozdemir H, Oto G, Deniz S, Kacar O, Basak AS, Cakir T, Sinav HU, Demir G. Genotoxicity and Cytotoxicity of novel 10B carrier ((2R)-4,5,6-trihydroxy-2(hydroxymethyl) tetrahydro-2H-pyran-3-yl)boronic acid. MedSci and Discovery 2014; 1(4): 96- 108.

13. Akan Z, Turkmen M, Cakir T, Reyhancan IA, Colak U, Okka M, et al. Modification of the radial beam port of ITU TRIGA Mark II research reactor for BNCT applications. Applied Radiation and Isotopes. 2015;99:110-6.

14. Akan Z, Demiroglu H, Avcibasi U, Oto G, Ozdemir H, Deniz S, Basak A. Complexion of Boric Acid with 2Deoxy-D-glucose (DG) as a novel boron carrier for BNCT. Medical Science and Discovery. 2014; 1(3):65-71

15. Hsu CF, Lin SY, Peir JJ, Liao JW, Lin YC, Chou FI. Potential of using boric acid as a boron drug for boron neutron capture therapy for osteosarcoma. Applied Radiation and Isotopes. 2011 Dec 31;69(12):1782-5

16. Crawford ED. Understanding the epidemiology, natural history, and key pathways involved in prostate cancer. Urology 2009; 73(5 suppl):S4-10.

17. Ferlay J, Shin HR, Bray F, Forman D, Mathers C, Parkin DM. Estimates of worldwide burden of cancer in 2008: GLOBOCAN 2008. Int J Cancer. 2010; 127:2893-917.

18. Perin NN. Global variation in cancer incidence and mortality. Curr. Sci. 2001; 81: 465-474.

19. Hudson T, Denis LJ. Europa Uomo: the European prostate cancer coalition. Recent Results Cancer Res 2007; 175:267-71.

20. Schroder FH, et al. Screening and prostate-cancer mortality in a randomized European study. $\mathrm{N}$ Engl $\mathrm{J}$ Med 2009;360(13):1320-8.

21. Gosselaar C, Roobol MJ, Schroder FH. Prevalence and characteristics of screen-detected prostate carcinomas at low prostate-specific antigen levels: aggressive or insignificant? BJU Int 2005;95(2):231-7.

22. Klotz L, Zhang L, Lam A, Nam R, Mamedov A, Loblaw A. Clinical results of longterm follow-up of a large, active surveillance cohort with localized prostate cancer. J Clin Oncol 2010;28:126-31.

23. Zelefsky MJ, Fuks Z, Hunt M, Lee HJ, Lombardi D, Ling $\mathrm{CC}$, et al. High dose radiation delivered by intensitymodulated conformal radiotherapy improves the outcome of localized prostate cancer. J Urol 2001;166:876-81.

24. Pollack A, Zagars GK, Starkschall G, Antolak JA, Lee JJ,HuangE, et al. Prostate cancer radiation dose response: results of the M.D. Anderson phase III randomized trial. Int J Radiat Oncol Biol Phys 2002;53:1097-105. 
25. Zelefsky MJ, Yamada Y, Fuks Z, Zhang Z, Hunt M, Cahlon $\mathrm{O}$, et al. Long-term results of conformal radiotherapy for prostate cancer: impact of dose escalation on biochemical tumor control and distant metastases-free survival outcomes. Int $\mathrm{J}$ Radiat Oncol Biol Phys 2008; 71:1028-33.

26. Barth RF, Soloway AH, Fairchild RG, Brugger RM. Boron neutron capture therapy for cancer. Realities and prospects. Cancer. 1992;70(12):2995-3007.

27. Takahara K, Inamoto $\mathrm{T}$, Minami K, Yoshikawa $\mathrm{Y}$, Takai T, Ibuki N, Hirano H, Nomi H, Kawabata S, Kiyama S, Miyatake SI. The Anti-Proliferative Effect of Boron Neutron Capture Therapy in a Prostate Cancer Xenograft Model. PloS one. 2015 Sep 1;10(9):e0136981.
28. Gifford I, Vreeland W, Grdanovska S, Burgett E, Kalinich J, Vergara V, Wang CK, Maimon E, Poster D, Al-Sheikhly M. Liposome-based delivery of a boron-containing cholesteryl ester for high-LET particle-induced damage of prostate cancer cells: a boron neutron capture therapy study. International journal of radiation biology. 2014 Jun 1;90(6):480-5.

29. Tanaka H, Sakurai Y, Suzuki M, Takata T, Masunaga S, Kinashi Y, Kashino G, Liu Y, Mitsumoto T, Yajima S, Tsutsui H. Improvement of dose distribution in phantom by using epithermal neutron source based on the $\mathrm{Be}(\mathrm{p}, \mathrm{n})$ reaction using a $30 \mathrm{MeV}$ proton cyclotron accelerator. Applied Radiation and Isotopes. 2009 Jul 31;67(7):S25861

Copyright (C) 2016 The Author(s); This is an open-access article distributed under the terms of the Creative Commons Attribution License (http://creativecommons.org/licenses/by/4.0), which permits unrestricted use, distribution, and reproduction in any medium, provided the original work is properly cited. All Rights reserved by international journal of Medical Science and Discovery. 